\title{
The short-term impact of the Covid-19 pandemic on livestock products and feed prices in Turkey
}

\author{
Savaş SARIÖZKAN ${ }^{1, a, ~}$, Aytaç AKÇAY ${ }^{2, b}$, Mehmet KÜÇÜKOFLAZ ${ }^{3, c}$, Güven GÜNGÖR $^{3, d}$ \\ ${ }^{1}$ Erciyes University, Faculty of Veterinary Medicine, Department of Animal Health Economics and Management, Kayseri, Turkey; \\ ${ }^{2}$ Ankara University, Faculty of Veterinary Medicine, Department of Biometrics, Ankara, Turkey; ${ }^{3}$ Erciyes University, Graduate \\ School of Health Sciences, Department of Zootechnics, Kayseri, Turkey. \\ aORCID: 0000-0003-2491-5152; ' $\mathrm{ORCID:} \mathrm{0000-0001-6263-5181;} \mathrm{'} \mathrm{ORCID:} \mathrm{0000-0003-3256-4735;}$ \\ dORCID: 0000-0003-3695-9343.
}

$\begin{gathered}\text { Correspondence Author: ssariozkan@erciyes.edu.tr } \\ \text { Received date: } 27.07 .2020 \text { - Accepted date: } 21.12 .2020\end{gathered}$
-

\begin{abstract}
This study aimed to investigate changes in the prices of animal products (meat, milk, eggs), and feed before and during the pandemic period on a sectoral basis in Turkey. The material for the study consisted of the prices of animal products (beef, lamb and, poultry meat, eggs, and milk) and feed collected from official institutions and producer associations in the period before (December 2019-February 2020) and during (March-May 2020) the pandemic. Considering the prices of investigated animal products, there were increases at different rates in all products during the pandemic (1.82-11.57\%). While the differences between producer prices of beef and broiler meat before and during the pandemic were found to be statistically significant $(\mathrm{P}<0.05)$, the changes in lamb meat and egg prices were not statistically significant. On the other hand, feed prices were found to be increased by $9.71-12.57 \%$. It was determined that the feed, which is the most critical input of producers, showed a significant increase $(\mathrm{P}<0.05)$ during the pandemic, especially in the poultry sector. During the pandemic, the highest reduction in livestock product/feed parity was experienced in the egg sector, with $-10.28 \%$. In conclusion, examined animal product prices increased during the pandemic period, but input prices increased more than products. In addition, it was determined that the producers had to produce with lower profitability according to the productfeed parity values, especially in the egg poultry sector during the pandemic period.
\end{abstract}

Keywords: Covid 19, feed, meat, milk, prices.

\section{Türkiye'de Covid-19 pandemisinin hayvansal ürün ve yem fiyatlarına kısa süreli etkisi}

Özet: Bu çalışmada, Türkiye'de pandemi öncesi ve pandemi dönemindeki hayvansal ürün (et, süt, yumurta) ve yem fiyatlarındaki değişimlerin sektörel bazda araştırılması amaçlanmıştır. Çalışma materyalini resmi kurumlardan ve üretici birliklerinden pandemi öncesi (Aralık 2019-Şubat 2020) ve pandemi sırasında (Mart-Mayıs 2020) elde edilen hayvansal ürün (sığır eti, kuzu eti, kanatlı eti, yumurta ve süt) ve yem fiyatları oluşturmuştur. İncelenen hayvansal ürünlerin fiyatları açısından değerlendirme yapıldığında, pandemi döneminde tüm ürünlerde farklı oranlarda artış yaşanmıştır (\%1,82-11,57). Pandemi öncesi ve sırasında sığır eti ve piliç eti üretici fiyatları arasındaki fark istatistiksel olarak anlamlı bulunurken $(\mathrm{P}<0,05)$, kuzu eti ve yumurta fiyatlarındaki değişiklikler istatistiksel olarak anlamlı bulunmamıştır. Diğer taraftan, girdi maliyetleri yönünden yaşanan değişiklikleri göstermesi bakımından yem fiyatları da incelenmiş ve \%9,71-12,57 oranında arttığı tespit edilmiştir. Üreticilerin en önemli girdisi olan yemin pandemi döneminde özellikle kanatlı sektöründe önemli düzeyde artış $(\mathrm{P}<0,05)$ gösterdiği belirlenmiştir. Pandemi sırasında hayvansal ürün/yem paritesindeki en fazla azalma -\%10,28 ile yumurta sektöründe yaşanmıştır. Sonuç olarak, pandemi döneminde hayvansal ürün fiyatları artmış ancak girdi fiyatlarında artış daha fazla olmuştur. Ayrıca üreticilerin pandemi döneminde başta yumurta tavukçuluğu olmak üzere ürün/yem paritesi değerlerine göre daha düşük karlılıkla çalışmak zorunda kaldıkları belirlenmiştir.

Anahtar sözcükler: Covid 19, et, fiyat, süt, yem.

\section{Introduction}

Covid-19, which emerged on December 12, 2019, in Wuhan Province, China, was declared a pandemic by the World Health Organization (WHO) on March 11, 2020, as it began to spread worldwide (21). The first Coronavirus case in Turkey was declared by the Ministry of Health on March 11, 2020, and the first death occurred on March 18, $2020(7,16)$. The rapid transmission of the virus through human contact, causing a significant number of deaths, has forced all countries to take radical measures. In this context; schools have been closed, domestic/international 
travel restrictions have been introduced, quarantine measures have been applied, the borders of countries have been closed (import/export), rapid vaccine and drug studies have been initiated, and respiratory equipment, masks, gloves, and disinfectant production have been increased. As a result, serious decisions were made that would profoundly affect all sectors and economies.

The livestock sector has continuous production and constitutes a significant part of the food supply, which is a basic need of people. During the pandemic period, it has been observed that the demand for products such as red meat, chicken meat, eggs, and milk has increased, especially in some households (except lower income families), where people have stayed at home. For this reason, despite this sudden increase in demand for animal products in the short term, price increases (partially speculative) have been experienced in the markets since supply could not respond in the same manner because of its production structure. According to the course of the pandemic, price increases in animal products have been shaped over time according to the behavior of consumers and changes in input costs (mainly feed). While it is thought that it will take time for the markets to stabilize in the near future, it may be easier to shape the supply according to the expectations of the market in the medium and long term with supporting measures such as capacity increase, incentives, and subsidies.

In Turkey, during this period, no additional measures have been needed to increase the production of livestock by the government. Only electricity, water, and credit payments have been postponed, and advantageous credit opportunities have been offered $(12,17)$. In addition, the problems encountered in the transfer of animal and animal products during the pandemic caused disruptions in animal feed supply and slaughter.

The most significant barrier to reveal the economic impact of the Spanish flu experienced in the world in 1918 was the lack of economic data (5). The current study not only reveals the effects of Covid-19 on the animal product and feed prices but also provides a basis for future studies

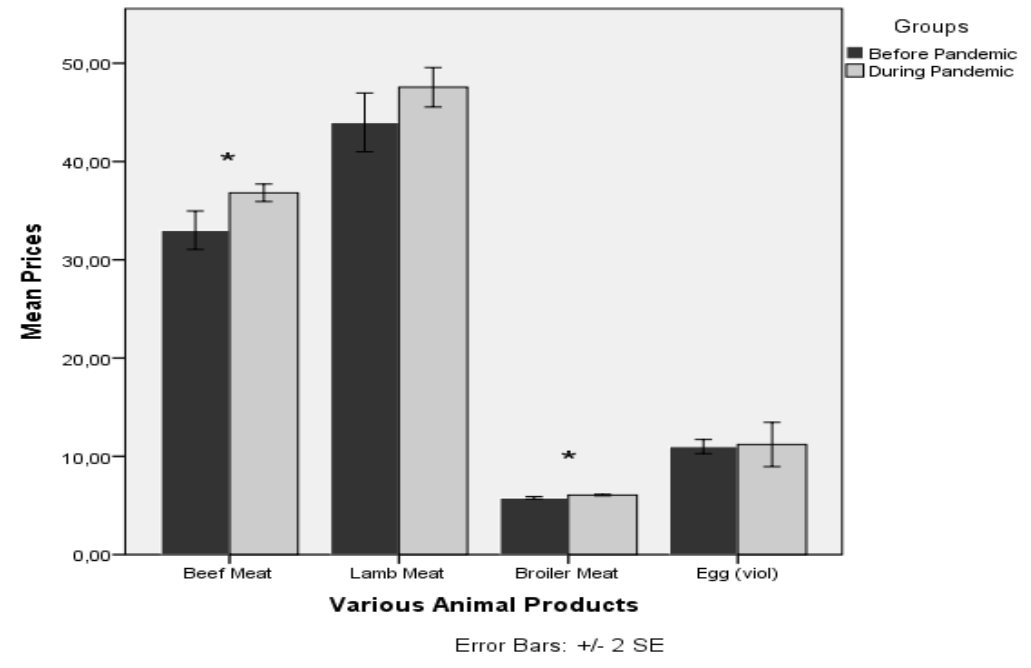

Figure 1. Changes in animal product prices before and during the pandemic period. on the long-term impact of the pandemic. This study aims to investigate changes in the prices of animal products (meat, milk, eggs) and feed (beef fattening, lamb, broiler, layer, and dairy feeds) before and during the pandemic period on a sectoral basis in Turkey.

\section{Materials and Methods}

The material for the study consisted of the prices of animal products (beef, lamb, and poultry meats, eggs, and milk) and feed (beef fattening, lamb, broiler, layer, and dairy feeds) collected from official institutions (Meat and Milk Board-ESK, the National Red Meat Council-UKON, the National Milk Council-USK) and producer associations (Kaytaş) in the period before (December, January, February) and during (March, April, May) the pandemic $(4,9,18,19)$. In addition, animal products and feed prices parities for the period before and during the pandemic were calculated using the following formula:

Product $/$ Feed Parity $=$ Animal product sale prices (producer) / feed price.

In the study, the prices before pandemic (December 2019-February 2020) and during pandemic (March-May 2020) were compared.

Statistical analysis: Monthly mean prices of livestock products and feed were considered in the statistical analysis. Student's t-test was used for the statistical significance control of the difference between the mean of the prices before and during the pandemic, with the Pearson correlation coefficient. Statistical analyses were performed with the SPSS 22.0 package program.

\section{Results}

In this study, animal product and feed prices along with product/feed parities for the periods before and during the pandemic were analyzed and presented as tables (Tables 1-3) and graphics (Figures 1-4). and the relationship between the variables was evaluated 

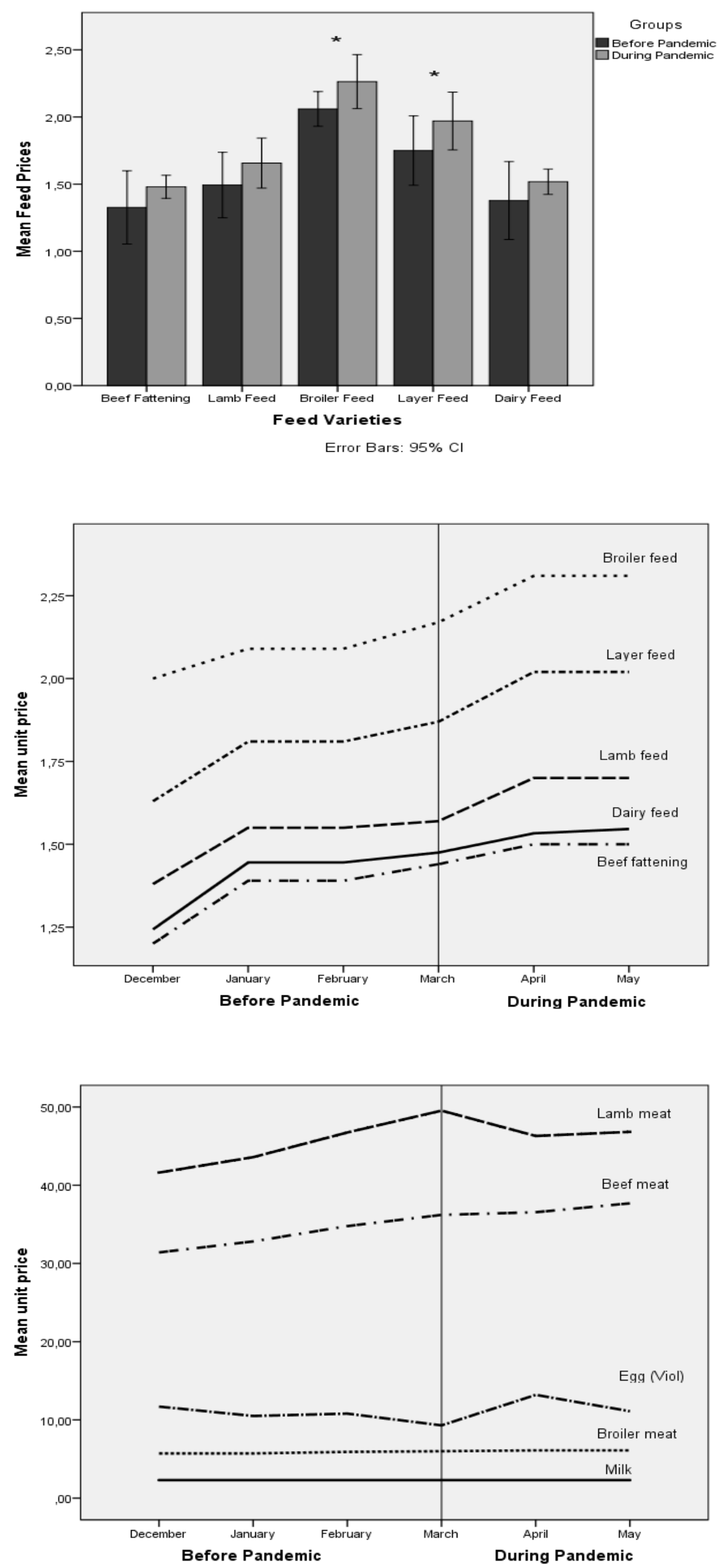

Figure 2. Changes in animal feed prices before and during the pandemic period.

Figure 3. Changes in animal feed prices before and during the pandemic period.

Figure 4. Changes in animal product prices before and during the pandemic period. 
Table 1. Various animal product prices (TL) and changes (\%) before and during the pandemic.

\begin{tabular}{|c|c|c|c|c|}
\hline Variables $^{*}$ & Groups & Means \pm Standard Error & Price Changes (\%) & $\mathbf{P}$ \\
\hline \multirow{2}{*}{ Beef meat } & Before pandemic & $33.00 \pm 0.98$ & \multirow{2}{*}{+11.57} & \multirow{2}{*}{0.024} \\
\hline & During pandemic & $36.82 \pm 0.45$ & & \\
\hline \multirow{2}{*}{ Lamb meat } & Before pandemic & $43.99 \pm 1.49$ & \multirow{2}{*}{+8.11} & \multirow{2}{*}{0.118} \\
\hline & During pandemic & $47.56 \pm 1.00$ & & \\
\hline \multirow{2}{*}{ Broiler meat } & Before pandemic & $5.78 \pm 0.07$ & \multirow{2}{*}{+4.84} & \multirow{2}{*}{0.020} \\
\hline & During pandemic & $6.06 \pm 0.04$ & & \\
\hline \multirow{2}{*}{$\operatorname{Egg}^{* *}$} & Before pandemic & $11.00 \pm 0.36$ & \multirow{2}{*}{+1.82} & \multirow{2}{*}{0.874} \\
\hline & During pandemic & $11.20 \pm 1.13$ & & \\
\hline
\end{tabular}

${ }^{*}$ Since milk prices have not changed, no comparison has been made. ${ }^{* *}$ Egg prices have been calculated over 30 viol.

Table 2. Prices (TL) and changes (\%) in animal feed before and during the pandemic.

\begin{tabular}{|c|c|c|c|c|}
\hline Variables & Groups & Means \pm Standard Error & Price Changes (\%) & $\mathbf{P}$ \\
\hline \multirow{2}{*}{ Beef fattening feed } & Before pandemic & $1.33 \pm 0.06$ & \multirow{2}{*}{+12.03} & \multirow{2}{*}{0.082} \\
\hline & During pandemic & $1.49 \pm 0.02$ & & \\
\hline \multirow{2}{*}{ Dairy feed } & Before pandemic & $1.38 \pm 0.07$ & \multirow{2}{*}{+10.14} & \multirow{2}{*}{0.118} \\
\hline & During pandemic & $1.52 \pm 0.02$ & & \\
\hline \multirow{2}{*}{ Lamb feed } & Before pandemic & $1.49 \pm 0.06$ & \multirow{2}{*}{+11.41} & \multirow{2}{*}{0.084} \\
\hline & During pandemic & $1.66 \pm 0.04$ & & \\
\hline \multirow{2}{*}{ Broiler feed } & Before pandemic & $2.06 \pm 0.03$ & \multirow{2}{*}{+9.71} & \multirow{2}{*}{0.021} \\
\hline & During pandemic & $2.26 \pm 0.47$ & & \\
\hline \multirow{2}{*}{ Layer feed } & Before pandemic & $1.75 \pm 0.06$ & \multirow{2}{*}{+12.57} & \multirow{2}{*}{0.048} \\
\hline & During pandemic & $1.97 \pm 0.05$ & & \\
\hline
\end{tabular}

Table 3. Feed parities of various animal products before and after the pandemic.

\begin{tabular}{|c|c|c|c|c|}
\hline Variables & Groups & Means \pm Standard Error & Parity Changes (\%) & $\mathbf{P}$ \\
\hline \multirow[t]{2}{*}{ Beef meat/feed parity } & Before pandemic & $24.94 \pm 0.74$ & \multirow{2}{*}{-0.16} & \multirow{2}{*}{0.972} \\
\hline & During pandemic & $24.90 \pm 0.27$ & & \\
\hline \multirow[t]{2}{*}{ Milk/feed parity } & Before pandemic & $1.68 \pm 0.09$ & \multirow{2}{*}{-9.52} & \multirow{2}{*}{0.195} \\
\hline & During pandemic & $1.52 \pm 0.02$ & & \\
\hline \multirow[t]{2}{*}{ Lamb meat/feed parity } & Before pandemic & $29.48 \pm 0.68$ & \multirow{2}{*}{-2.38} & \multirow{2}{*}{0.674} \\
\hline & During pandemic & $28.78 \pm 1.39$ & & \\
\hline \multirow[t]{2}{*}{ Broiler meat/feed parity } & Before pandemic & $2.81 \pm 0.04$ & \multirow{2}{*}{-4.63} & \multirow{2}{*}{0.087} \\
\hline & During pandemic & $2.68 \pm 0.04$ & & \\
\hline \multirow[t]{2}{*}{ Egg/feed parity } & Before pandemic & $6.32 \pm 0.43$ & \multirow{2}{*}{-10.28} & \multirow{2}{*}{0.361} \\
\hline & During pandemic & $5.67 \pm 0.46$ & & \\
\hline
\end{tabular}

Considering the prices of investigated animal products, there were increases at different rates in all products during the pandemic (1.82-11.57\%). The differences between producer prices of beef and broiler meat before and during the pandemic were found to be statistically significant $(\mathrm{P}<0.05)$, and changes in lamb meat and egg prices were not statistically significant (Table 1).

On the other hand, to show the changes in terms of input costs, feed prices were also examined and were found increased by $9.71-12.57 \%$ during the pandemic period. It was determined that the feed, which is the most critical input of producers, showed a significant increase $(\mathrm{P}<0.05)$ during the pandemic, especially in the poultry sector (Table 2).
When the feed parities of various animal products are examined, it is possible to say that the parity decreases numerically out of the favor of the producer in all products. During the pandemic, the lowest parity was experienced in the egg sector, with $10.28 \%$ (Table 3 ).

As seen in the graph (Figure 3), a sudden rise (10$12 \%$ ) in feed prices was experienced due to an increase in the exchange rate with the emergence of the first cases (March 2020) in Turkey.

\section{Discussion and Conclusion}

An animal product supply chain consists of different actors such as the producer, industry/business, transportation/logistics, storage, and retail services (2). The operation of these actors in a particular order is 
essential in terms of connecting the consumers sustainably to the animal products in the market. However, measures taken such as curfew, import/export ban, inter-provincial travel restrictions) in the pandemic period in Turkey that put pressure on the sector and increased uncertainty for the future has been an obstacle for the continuity of production. On the other hand, since feed ingredients such as corn and soybeans are imported, price increases have been experienced due to the increase in foreign exchange rates and difficulties in obtaining these feedstuffs in Turkey. Also, the absence of policies that encouraged production in animal husbandry during the pandemic period raised future concerns in terms of sustainability of production. Moreover, the disruptions experienced in the logistics stages of animal products and raw materials caused deterioration in products and an increase in waste. The panic that occurred in the first days when curfew restrictions were applied in the pandemic period led to the stockpiling of basic needs by the public (including animal products), and crowding was experienced in shopping centers.

The impact of the Covid-19 pandemic on animal products and feed prices has been evaluated in some other countries $(1,3,6,8,13,14,20)$, However, to the best of the present authors' knowledge, there is no study investigating the effects of the Covid-19 pandemic on animal products and feed prices in Turkey.

In all the animal products examined in this study, price increases were experienced, and beef meat (11.57\%) was the most affected livestock product in Turkey during the three-month pandemic period examined. A possible reason of this increase may be due to scarcity of supplying the beef cattle and meat to the market in this period (seasonal effect), and reflection of increased feed prices on production costs. Due to lambing season, price increases in lamb meat $(8.11 \%)$ has been more limited compared to beef meat during the pandemic period.

On the other hand, there was a quite limited increase in egg prices $(1.82 \%)$ during the pandemic period. Due to the higher egg production capacity of Turkey and interruption in the exportation of the eggs, a market supply shortage was not experienced, which resulted in a negligible increase in egg prices. However, considering the feed prices, the poultry sector was negatively affected in this period due to the high dependence of feed ingredients (corn, soybean, etc.) on importation. When the animal product/feed parity is evaluated together, it is understood that the parity has decreased the most in the poultry sector, especially in egg poultry.

Similar with our study, price increase in meat was reported as significant and egg prices were not significantly affected during the pandemic period in Europe (1).

In Turkey, in the pandemic period, warnings such as stay-at-home and maintain social distance as well as travel restrictions and the enforcement of a partial curfew has changed consumer behavior due to the uncertainty of the future. Thus, the demand for animal products was increased at the beginning of the pandemic period. Similar effects were seen in other countries (10). Although the impact of the pandemic on the producers is not yet entirely clear, considering together the prices and parities, it is possible to say that the pandemic reduces the profitability of producers in the short term in Turkey. Considering parities, the egg and milk producers were the most affected by the pandemic in the evaluated period, whereas the impact on the red meat sector was more limited. However, feed prices in the USA between January and May 2020 (6) and slaughtered beef prices in Canada decreased by $16 \%$ (11). Although it has been calculated that the pandemic caused significant losses in animal products and feed in the USA (8), beef producers in Canada expect recovery to start in the autumn of 2020, and to return to normal in early 2021 (13).

In the present study, the changes in the prices of animal products and inputs (feed) on the producer basis during the pandemic in Turkey were evaluated. In addition, it is of importance to evaluate the effects of a pandemic on consumer behavior in terms of livestock products. Despite the increase in animal product prices during the pandemic period, the increase in demand is thought of as a disaster-specific and research-worthy consumer behavior. Because demand elasticity decreased in this period (8), the order of importance of the needs of consumers changed, and food products, especially animal products, had more priority.

Beside Covid-19 pandemic, some different factors may affect the prices of livestock products and feed such as season, exchange rates and inflation. For example, similar increase in price of beef meat $(9.17 \%)$ was seen a year before in Turkey. Exchange rates and inflation were increased $12.67 \%$ and $13.9 \%$ during the pandemic period compared to before the pandemic period in Turkey, respectively (15).

It is difficult to increase the supply quantity in a short time due to the structure of production in livestock production. For example, at least 40-45 days are required for broiler meat production, 90-180 days for beef production, 120-130 days for egg production, and 150 days in lamb production. In the pandemic period, the producers' failure to respond to the increasing demand for animal products in a short time can only be explained by the production period. For these reasons, especially in extraordinary situations, such as the pandemic period, products such as broilers and eggs, that can increase supply in a shorter time, are essential. Additionally, it is thought that additional support and subsidies are needed to increase animal production. In this way, the implementation of measures that will both encourage 
production and secure supply will be beneficial. The longterm effect of the pandemic on the supply of animal products clearly will be more evident in the future. The present study, demonstrating as it does the short-term effects of the pandemic on the animal product and input prices, is thought to be a basis for future studies investigating the long-term effects of the Covid-19 pandemic on animal production in Turkey.

In conclusion, animal product prices increased during the pandemic period, but input prices increased more than products. An increase in foreign exchange prices and dependency are thought to be responsible for this situation. In addition, it was determined that the producers had to produce with lower profitability compared to the product/feed parity values, especially in the egg poultry sector during this period.

\section{Financial Support}

This research received no grant from any funding agency/sector.

\section{Ethical Statement}

This study does not present any ethical concerns.

\section{Conflict of Interest}

The authors declared that there is no conflict of interest.

\section{References}

1. Akter S (2020): The impact of COVID-19 related 'stay-athome'restrictions on food prices in Europe: findings from a preliminary analysis. J Food Secur, 12, 719-725.

2. Cullen MT (2020): Coronavirus food supply chain under strain what to do? Available at: http://www.fao.org/3/ ca8308en/ca8308en.pdf. (Accessed Jun 15,2020).

3. Dennis EJ (2020): Has Covid-19 impacted price-weight relationships and value of gain? Extension Farm and Ranch Management. Available at: https://digitalcommons.unl.edu/ cgi/viewcontent.cgi?article $=1031 \&$ context $=$ ageconfarmmg mt. (Accessed Apr 29, 2020).

4. ESK (2020): Hayvan Alım Fiyatları. Available at: https://www.esk.gov.tr/tr/11931/Alim-Fiyatlari. (Accessed Jun 10, 2020).

5. Garrett TA (2007): Economic effects of the 1918 influenza pandemic: Implications for a modern-day pandemic. Federal Reserve Bank of St. Louis. Available at: https://www.stlouisfed.org/ /media/files/pdfs/communitydevelopment/research-reports/pandemic_flu_report.pdf. (Accessed May 8, 2020).

6. Gertner D, Dennis E (2020): Impact of Covid-19 on demand for distillers grains from livestock operations. Cornhusker Economics June 3, 2020. Available at: https://agecon.unl.edu/cornhusker-economics/2020/Impact -of-COVID-19-on-Demand-for-Distillers-Grains-fromLivestock-Operations.pdf. (Accessed Jun 3, 2020).
7. Göncüoğlu M, Ayaz N, Cengiz G, et al (2020): Emerging details about COVID-19 and chronology of the pandemic in Turkey. Ankara Univ Vet Fak Derg, 67, 323-332.

8. Hart CE, Hayes DJ, Jacobs KL, et al (2020): The impact of Covid-19 on Iowa's corn, soybean, ethanol, pork, and beef sectors. CARD Policy Briefs. Available at: https://www.card.iastate.edu/products/publications/pdf/20p b28.pdf. (Accessed Apr 25, 2020).

9. Kaytaş (2020): Yumurta Fiyatları. Available at: http://fiyatlistesi.kaytas.com.tr/Product/ListAll. (Accessed Jun 10, 2020).

10. Lusk J (2020): Impacts of coronavirus on food markets. Available at: http://jaysonlusk.com/blog/2020/3/16/impactsof-coronavirus-on-food-markets. (Accessed Jun 12, 2020).

11. McMillin D (2020): Covid-19 pandemic sees cattle markets. Canadian cattlemen. Available at: https://www.canadiancattlemen.ca/livestock/beefcattle/cov id-19-pandemic-sees-cattle-markets-plunge/. (Accessed Jun 17, 2020).

12. Resmi Gazete (2020): T.C. Ziraat Bankası A.Ş. ve Tarım Kredi Kooperatiflerince Tarımsal Üretime Dair Düşük Faizli Yatırım ve İşletme Kredisi Kullandırılmasına İlişkin Uygulama Esasları Tebliği. Tebliğ No: 2020/4. Available at: https://www.resmigazete.gov.tr/eskiler/2020/03/ 20200325-10.htm. (Accessed Apr 12, 2020).

13. Rude J (2020): COVID-19 and the Canadian cattle/beef sector: Some preliminary analysis. Cand J Agr Econ, 68 , 207-213.

14. Seleiman MF, Selim S, Alhammad BA, et al (2020): Will novel coronavirus (Covid-19) pandemic impact agriculture, food security and animal sectors? Bioscience J, 36, 13151326.

15. T.C. Merkez Bankası (2020): Döviz kurları. Available at: https://www.tcmb.gov.tr/wps/wcm/connect/TR/TCMB+T R/Main+Menu/Istatistikler/Doviz+Kurlari. (Accessed Oct 12, 2020).

16. T.C. Sağlık Bakanlığı (2020): Covid-19, Türkiye'deki güncel durum. Available at: https://covid19.saglik.gov.tr/. (Accessed Apr 15, 2020).

17. T.C. Tarım ve Orman Bakanlığı (2020): Orman köylü ve kooperatiflerinin kredi taksitleri kovid-19 nedeniyle ertelendi. Available at: https://www.tarimorman.gov.tr/ Haber/4514/Orman-Koylu-Ve-Kooperatiflerinin-Kredi-

Taksitleri-Kovid-19-Nedeniyle-Ertelendi. (Accessed May 1, 2020).

18. UKON (2020): Kırmızı Et Alım Fiyatları. Available at: http://www.ukon.org.tr/Fiyatlar.aspx. (Accessed Jun 10, 2020).

19. USK (2020): Çiğ Süt Fiyatları. Available at: https://ulusalsutkonseyi.org.tr/2019-yili-cig-sut-fiyatlari2019-2583/. (Accessed Jun 10, 2020).

20. Weersink A, Von Massow M, McDougall B (2020): Economic thoughts on the potential implications of COVID19 on the Canadian dairy and poultry sectors. Cand J Agr Econ, 68, 195-200.

21. WHO (2020): Director-General's opening remarks at the media briefing on Covid-19. Available at: https:/www.who.int/dg/speeches/detail/who-directorgeneral-s-opening-remarks-at-the-media-briefing-oncovid-19---11-march-2020. (Accessed May 25, 2020). 